\title{
Szili Katalin \\ Az idő kifejezésének kérdéséhez a magyar nyelvben, különös tekintettel a tér és idő fogalmának összefüggésére
}

\begin{abstract}
This paper adopts a cognitive linguistic approach to the conceptualisation of time in Hungarian. Firstly, it looks at the way in which morphological devices, case markers and postpositions designed to express spatial directions express time in order to identify the features of the concept of space used by cognition to connect the two entities. By detecting the presence of time in the concept of space in a few cases, the analysis casts some doubt on the interpretation of space exclusively as a source domain. Secondly, the paper describes the main time metaphors of Hungarian. The vast majority are universal but some belong to a separate category of language-specific image schema metaphors associated with the directions UP, DOWN and OUT. The results of both analyses demonstrate that the concept of time in the Hungarian speech community not only includes universal components but also culture and language-specific features.

Keywords: conceptual metaphor, space, time, events, culture
\end{abstract}

\section{Bevezető}

Dolgozatomban a tér- és az időkoncepciók összekapcsolódásával, a köztük levő viszony nyelvi tükröződésével foglalkozom a magyar nyelvben kognitív keretben. Első lépésként a tér és idő megjelenítését szolgáló közös morfológiai eszközökön keresztül mutatom be találkozásukat, vagyis azt, hogy a magyarban - más nyelvekkel megegyezően - a térviszonyok kifejezését szolgáló nyelvi elemek nagyrészt időfunkciókkal is bírnak. Az elemzésben szempontnak választottam azt is, hogy az eredetileg háromdimenziós térbeli jelentések milyen módosulásokon mennek keresztül lineáris és horizontális időszemléletünk hatására. Ebben a nemcsak néhány kiragadott példára támaszkodó, hanem teljességre törekvő súlypontos részben a tárgyalás menetét az irányjelölő ragok háromszor hármas rendszere szabta meg. Második lépésként a nyelvünkben meglévő időmetaforák feltérképezésére vállalkozom a terjedelem megszabta határok közé szorítva taglalásukat. Itt az eddigi szakirodalmon kívül tudatosan támaszkodtam az igekötők vizsgálata során nyert eredményeimre, így kitérek a bennük foglalt képi sémák hatására az idő strukturálásában. 
Szili Katalin:

Az idö kifejezésének kérdéséhez a magyar nyelvben, különös tekintettel a tér és idö fogalmának összefüggésére Argumentum 17 (2021), 399-417

Debreceni Egyetemi Kiadó

DOI: $10.34103 /$ ARGUMENTUM/2021/20

\subsection{Az elméleti keretröl}

Tárgyamat, miképpen a dolgozat címe sugallja, a kognitív nyelvészet keretén belül taglalom. Lényegében nem is tehettem másképpen, hiszen az idő, ez a filozófiát, a fizikát, de a költészetet, kulturális antropológiát, pszichológiát, neuropszichológiát és még több egyéb tudo mányterületet érintő, érdeklő absztrakció, amely egyszerre megfoghatatlan és nagyon valós, végtelen és drámaian véges, zömében nem saját ,jogán”, hanem gazdagabb, tapasztalati úton hozzá férhetőbb fogalmak analogikus leképzése útján, metaforikusan és metonimikusan konceptualizálódik a tudatunkban. Általánosságban példázza tehát a konceptuális nélkülözhetetlenség (conceptual indispensability) jelenségét, amikor is egy fogalom metaforikus kiterjesztés nélkül nemigen létezik. A hangsúly az előző mondatban az általánosságban határozón van, mivel vannak a hely- és irányjelölö esetragokon kívül más időt jelölő morfémák, gondolok többek között a birtokos személyjel és a tárgyrag időtartamot tükröző szerepére - két éve nem láttalak; öt hetet töltöttem ezzel a munkával -, valamint az eszközhatározó ragra: idövel minden megoldódik; az esemény egy gongütéssel vette kezdetét.

Az elméleti alapvetések ismertetését szükre szabtam, csak a legszükségesebb, az elemzéseimet alátámasztó megállapításokra szorítkozom. Tettem ezt több okból. Először is az elvégzendő gyakorlati feladatok nagysága miatt: az első részben járatlan úton kellett haladnom: a hatvanashetvenes években született alapos leíró nyelvtanaink időhatározókkal foglalkozó fejezetei konstatálták ugyan az irányjelölő esetragok időt jelölő funkcióját (többek között Rácz 1968), ezzel közvetve a tér és az idő közötti összefüggések létét, a hasznos megfigyelések kognitív magyarázata azonban ez idáig elmaradt. A nyelvünkben meglévő időmetaforák összefoglaló leírása szintén terjedelemigényesnek bizonyult: itt ugyan bőven támaszkodhattam elöképekre (Ahrens \& Huang 2002; Kövecses 2005a; Radden 2006, 2011; Kövecses \& Benczes 2010; Moore 2014 stb.), de a magyar nyelvre vonatkoztatva tudtommal Szamarasz Vera Zoé dolgozata foglalkozik időmetaforákkal, azon belül a kognitív feldolgozásuk mechanizmusával (Szamarasz 2006: 99109). A rövidítés mellett szólt az az örvendetes tény is, hogy a fogalmi metaforák elmélete a nyelvészeti köztudat részévé vált a Lakoff és Johnson alapdolgozata óta eltelt negyven évben, nem kis részben a teória klasszikusainak (Lakoff \& Johnson 1980, 1999; Lakoff 1993, 2008; Kövecses 2005a, Fauconnier \& Turner 2008 stb.) köszönhetően. A szerencsés egybeesésből adódóan magyarul is elérhetők a kognitív nyelvészetről, azon belül is a metaforáról szóló ismeretek (Kövecses 2005b, 2006; Kövecses \& Benczes 2010).

A fogalmimetafora-elmélet alapállítása szerint az absztrakt dolgokat tapasztalati úton hozzáférhetőbb fogalmak analogikus leképzésein keresztül értelmezzük, következésképpen minden metafora mögött a megfelelések szisztematikus rendszere húzódik meg. Lakoff és Johnson szerint az összes metaforikus fogalmat meglehetősen szük tapasztalati kör strukturálja (Lakoff \& Johnson 1980). Az egyik ilyen meghatározó tapasztalati forrás a tér, a térbeli relációk (fent, lent, elöl, hátul stb.), nem véletlen tehát, hogy a térbeli percepciók megfeleltetésének kognitív müvelete kitüntetett figyelmet kapott a fogalmimetafora-elmélet szakirodalmában (Lakoff \& Johnson 1980, Lakoff \& Johnson 1999; Lakoff 1993; 2008; Kövecses 2002). Mivel a témám szempontjából a tér domináns forrástartomány, a két fogalom elemeinek kapcsolata központi kérdésnek mondható az időkoncepciókat taglaló kognitív aspektusú publikációkban (többek között: Boroditsky 2000, 20001; Gentner \& Boroditsky 2002; Radden 2006, 2011; Moore 2006, 2014; Waliński 2014). A térbeliség megélése általános és közös emberi tapasztalásunk: a körülöttünk levő világot térként érzékeljük és fogjuk fel, amelyben a tárgyak, dolgok elhelyezkednek, a gépek, az élölények, így mi is, mozgunk. A többféle érzékszervvel összegyüjtött tudások 
Szili Katalin:

Az idö kifejezésének kérdéséhez a magyar nyelvben, különös tekintettel a tér és idö fogalmának összefüggésére Argumentum 17 (2021), 399-417

Debreceni Egyetemi Kiadó

DOI: 10.34103/ARGUMENTUM/2021/20

ezért igencsak hatékonynak bizonyultak az önmagával értelmezhetetlen időfogalom megkonstruálására.

AZ IDŐ TÉR fogalmi metafora nyelvi manifesztációi, azaz a térbeli kifejezések idő értelemben történő használata, az időmetaforák léte univerzális jelenségnek mondható. Rögtön hozzá kell tennem azonban, hogy a konceptualizációs folyamatok komplex, több tényezőtől meghatározott történeti, anyagi, geográfiai, szociokulturális kontextusban realizálódnak, következésképpen kultúraspecifikus jegyekkel bírnak. (A metaforák és a kultúra összefüggésérool: Kövecses 2005b; Kövecses \& Benczes 2010: 95-114; Caballero \& Ibarretxe-Antuñano 2014). A kultúra összetevőinek, így a hiteknek, hiedelmeknek, értékeknek, attitűdöknek, szokásoknak a helye a metaforizációban megítélésem szerint még további kutatásokat kíván, örvendetes viszont, hogy a szimbólumok és a metaforák kapcsolatáról önálló monográfia született magyarul (Szabó 2015). Kevesebb szó esik ellenben a szakirodalomban a nyelvi determináltságról, vagyis arról a tényről, hogy a metaforák egyfelől az adott nyelvben meglévő már meglévő képek rend szerébe is szervülnek, másfelől a grammatikai rendszer által is meghatározottak (bár végső soron a nyelvi formák is tapasztalások nyelvi leképzései). Mind a kulturális, mind a nyelvi beágyazottságot fontos tényezőnek tekintem, és elemzéseimben tudatosan figyelembe veszem őket.

A Lakoff és Johnson által említett szük tapasztalati körök közül a téren kívül a tartály mint fizikai, ontológiai fogalom, illetve az események, cselekvések töltenek be lényeges szerepet az időfogalom megalkotásában. A 3. pontban taglalt metaforák azonosításában a legnagyobb nehézséget megfogalmazásaik és osztályozásaik változatossága jelentette: AZ IDŐ PÉNZ metaforának példának okáért Lakoff és Johnson ismeri AZ IDÖ ERŐFORRÁS (TIME AS A RESOURCE) változatát (1980: 7 -9), ami Evansnál is megvan (2003). Szokásos az idő megszemélyesítéseit külön metaforaként megfogalmazni (AZ IDŐ MINT VÁLTOZTATÓ, MINT TOLVAJ, MINT ARATÓ, MINT ÜLDÖZÖ - TIME AS A CHANGER, AS A THIEF, AS A REAPER, AS A PURSUER). De léteznek olyan metaforák is, amelyekben az idő áttételesen mint esemény, cselekvés, állapot vagy folyamat jelenik meg: AZ ÉLET UTAZÁS, AZ ÉLET EGY NAP, A HALÁL TÁVOZÁS, A HALÁL VÉGÁLLOMÁSRA ÉRKEZÉS. Ezeket kizártam a vizsgálataimból, és csak az időkoncepció részét képező főbb jegyekhez - a múlásához, a kiterjedéséhez; az eseményeknek színteret adó képességéhez, a mérhetőségéhez; a szociokulturális értékeihez - köthetőket emeltem ki.

\section{A tér és az idő kifejezését szolgáló közös morfológiai, lexikai eszközök}

Az, hogy a helyviszonyok kifejezésére használt eszközök az idő megjelenítését is szolgálják, univerzális jelenség a nyelvekben. Nincs ez másképp a magyarban sem, ezért feltételezhetjük, hogy hely- és irányjelölő esetragjaink gazdagsága hasonlóan cizellált időjelölés lehetőségét rejti magában. Mint ismeretes, a magyarban a helyek és irányok pontos jelölésére a hol?, hova? honnan? kérdésekre felelő háromszor hármas, a bennlevőséget, rajtalevőséget és mellettiséget magába foglaló, funkcionálisan körülhatárolt formai rendszer áll a rendelkezésünkre (lásd az 1. táblázatban a megfelelő kérdéseket). A körülhatároltságon azt értem, hogy meghatározott térbeli feltételek mellett a hol? kérdésre válaszolva csak a hozzá tartozó három esetrag közül választhatunk az adott szituációtól függően, a hova?, honnan? kérdésekre adandó feleletekben pedig az adott jelentéskategórián belül maradva kell egyeztetni az esetragokat és az aktuális helyzeteket. A rajtalevőség ragjaival illusztrálva az előbbieket: Péter a téren van, Anna a buszon ül mondatok határozói a hova? kérdésre térre, buszra, honnan? kérdésre térröl, buszról alakot vehetnek fel. Az iménti ragok arra is figyelmeztetnek, hogy az egyes beszélőközösségek 
térreprezentációi eltérőek lehetnek, mert a tapasztalt valóság más-más mozzanatát ragadják meg, de a kultúrájuk dimenziói is hatással vannak rájuk. A busz rajtalevőségre utaló ragjai nagy valószínüséggel a lovon ülés, szekéren való utazás analógiájára alakultak ki az angolban és a magyarban is, míg a német ezt az összefüggést mellözve a közlekedési eszközök tartály jellegét emeli ki: in dem Bus. Persze megtörténhet egy nyelven belül is, hogy egy-egy entitás két- vagy háromdimenziós formát egyaránt ölthet: sokáig bámulta a jegenyék hosszú, keskeny árnyékát - olvasgatott egy keveset az árnyékban.

No de nézzük az 1. táblázatot, követve az egyes helyjelölő morfémák időjelölő szerepeit! Általánosságban kijelenthetjük róluk, hogy - a jelen nyelvállapotot alapul véve - mindegyik hely- és irányrag poliszemantikus: elsődlegesen valamilyen térbeli viszonyt, irányt adnak meg, másodlagosan pedig időt (most egyéb funkcióikról nem beszélve). Elemzési kiindulópontként fogadjuk el, hogy megfeleléseik nem véletlenszerüek, és a térről szerzett tapasztalataink kerültek át, vivődtek át a jóval absztraktabb időre. A térbeli jelentések elsődlegességének több bizonyítéka is van: először is míg számos időre vonatkoztatható hely- és irányjelölő rag, névutó létezik, csak hosszas keresgélés után akadunk olyan időre utaló morfémára, amely helyre is alkalmazható: Haspelmath (1997) a depuis „óta” prepozíciót találta a franciában: depuis la fenětre ,az ablaktól” (idézi Radden 2011: 1). A magyarból ilyen esetet (most még) nem tudok említeni, a klasszikus temporalis ragként számon tartott -kor ugyanis kizárólag időre alkalmazható, ahogy az angol during „közben, alatt, folyamán” elöljáró. Az alábbi részletes elemzések azonban szolgálnak majd néhány ellenpéldával.

Fontos hangsúlyozni azonban, hogy a tér $\rightarrow$ idő leképzések nem egy az egyben megvalósuló, hanem inkább részleges egyezésekre épülnek, már csak objektív okokból is: a tér háromdimenziós, az idő egy; a térbeli mozgás reverzibilis, visszafordítható (kiment a házból, aztán visszament), az időbeli irreverzibilis (*délelött tanult, majd mégsem tanult); a tér a tárgyak helyszíne, az idő az események közege (Radden 2011). Emellett azt sem hagyhatjuk figyelmen kívül, hogy az időfunkciók létrejöttét (is) alapvetően kommunikációs célok, szükségletek irányítják. Ebből következően a közöttük meglévő metaforikus kapocs ellenére az egyes morfémák különféle mértékű „távolodást, önállósodást” mutathatnak a forrástartományaiktól.

\subsection{Az esetragok idökifejezö szerepe és a lineáris idösík}

Elsőként foglalkozzunk a tér háromdimenziós voltának és a lineáris idősíknak a kapcsolatával. Mint ismeretes, az idő múlását a nyugati kultúrákban megszokottan lineárisan, balról jobbra haladva egydimenziósnak képzeljük el, láttatjuk, lásd 1. ábra.

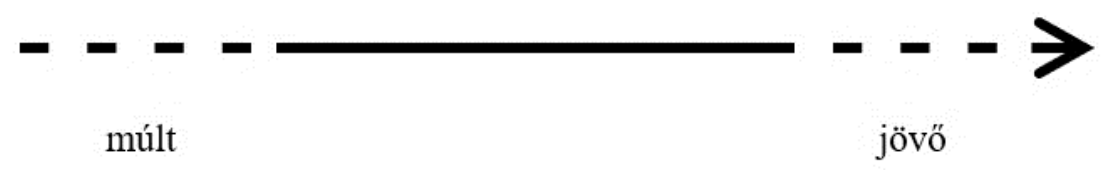

1. ábra. A balról jobbra haladó időkép

Az 1. ábrában ott van az idő végtelenségének gondolata is, hiszen sem a múlt kezdőpontja, sem a jövő végpontja nem ismert. Az eseményeket és a pontszerủ vagy szakasz jellegű időegységeket erre a lineáris idővonalra helyezzük el, de ekkor már támaszkodunk a fizikai tér kiterjedésének dimenzióira, tehát egydimenziósból két- vagy háromdimenzióssá alakulhatnak a szituációk (Radden 2011: 3). Az inessivusi -ban, -ben legalább két, három vagy minden oldallal való 
Szili Katalin:

Az idö kifejezésének kérdéséhez a magyar nyelvben, különös tekintettel a tér és idö fogalmának összefüggésére Argumentum 17 (2021), 399-417

Debreceni Egyetemi Kiadó

DOI: 10.34103/ARGUMENTUM/2021/20

határoltságot, tartályszerü térbeli testet feltételez. A tartálynak határai, oldalai vannak, amelyek közrefogják a benne levő dolgokat, személyeket: a gyerekek a szobában/a kertben játszanak; egy órát álltam sorban. A TARTÁLY ontológiai metafora határoltságban összpontosuló sémája képződik le az események, cselekvések időbeli megjelentetését szolgáló, AZ IDŐ TARTÁLY metaforában, amikor is az inessivusi rag jelölte háromdimenziósnak konstruált időegységben az események úgy foglalnak helyet, mint a körbezárt térben a tárgyak: ebben az évben befejezem a könyvem; a 21. században több kihívás elött áll az emberiség. A magyar nyelvben leginkább a nagyobb időperiódusokhoz (hónap, év, évszázad, évezred) ragasztva fordul elő. Az időegységek tartályként való felfogása nagyon is gyakorlati célt szolgál, egyfelől a határaik, másfelől a beléjük foglalt cselekvések, események pontos elválasztását: januárban hideg van, februárban már hosszabbodnak a napok, márciusban melegedik az idő. Annak okát, hogy a pontszerü vagy rövidebb időszakaszra utaló és a deiktikus kifejezések szintén inessivusi raggal állnak, a nézőpont megválasztásában látom: a tartállyal, amelynek belseje teret feltételez, mintegy kitágul az eredetileg rövid időegység, így események kerülhetnek bele: ebben a pillanatban/percben, minutumban megtörtént a baj. A rag e szerepét, a TARTÁLY metaforával való egyértelmü kapcsolata ellenére funkcionális önállóság jellemzi, ami alakilag elkülönülő, egyértelmủen időre vonatkozó kérdőszóban testesül meg: mikor?

A hova? honnan? kérdésekre felelő -ba- -be, -ból, -böl változatainak idő használatában szintén ott van a tartály kép: nemrég léptünk át a 21. századba, máris eltelt belöle két évtized.; Az a kastély a 18. századból való; vissza a 20. századba. Miképpen az igék jelzik, események, dolgok, tárgyak időintervallumba helyezését, onnan való kiemelését fejezik ki, és nem az abban való „elhelyezkedésüket”, így gyakoriságuk elmarad az inessivusi végződésétől. Az interneten a században gyorskeresése közel 5 millió találatot hozott, a századba formáé 298 ezret. A csekélyebb kommunikációs érték lecsapódik abban is, hogy a tér- és időviszonyokra vonatkozó kérdéseik nem különültek el: hova?, honnan? (lásd 1. táblázat).

A superessivusi -on rajtalevőséget kifejező eredeti tartalmában két tárgy közvetlen, egy közös felületen való kontaktusát jelzi, az egyik az ott lévő, a másik a tartó tárgy felülete. $A$ könvvek a polcon vannak mondatban a könyvek felületei találkoznak az őket tartó polc felületével. Idő értelmének létrejöttét e kétdimenziós érintkezési helyzet motiválhatta: a hét, a hét napjaival álló superessivusi rag azt sugallja, hogy a megnevezett időegységek felületként „tartják” a rajtuk elhelyezett eseményeket: ezen a héten sokat olvasok; szerdán, pihenek.

A rag hova? honnan? kérdésre válaszoló változatainak idő értelmében a felületi érintkezés mozzanata áttételesebb lett, más dimenziókat kapott, és ezzel új jelentéselemeket vett fel. A -ra, -re sublativusi rag felületi érintést jelöl, amely teljesülésekor lehet a tartó felületet tekintve részleges (az asztalra tette a könyvet), de lehet teljes is: az asztalra teritette az abroszt. Az első példában a könyv az asztal egy részével érintkezik, a másodikban az abrosz és az asztal felületének találkozása teljes. Ezt a kettősséget azért kellett kiemelnem, mert összefügg a rag kétféle időjelentésével. A részleges érintkezés pontszerüségként konceptualizálódik a mikorra? kérdésre felelő előfordulásában: 7-re odaérek. Célhatározói értelmében ellenben időszakaszt jelenít meg, amelynek kiterjedése megfelel a referált események, cselekvések időtartamának: ha azt mondom, hogy 2 hétre utazunk a Balatonra, az ott tartózkodásunk ideje azonos a határozó ragos időperiódussal, következésképpen egyezésükben a teljes felületi érintkezés eleme jelenik meg. Kérdése, a mennyi időre? mellett az időfunkció függetlenedésének bizonyítéka az is, hogy ennek a használatának nincs hely megfelelöje: ?1 kilométerre futok.

A sublativusi -ra, -re térre és időre alkalmazásának van egy másik, szorosabb kapcsolódást mutató változata is. A Pécs 198 kilométerre van Budapesttöl - Pécs két órára van Budapesttöl 
Szili Katalin:

Az idö kifejezésének kérdéséhez a magyar nyelvben, különös tekintettel a tér és idö fogalmának összefüggésére Argumentum 17 (2021), 399-417

Debreceni Egyetemi Kiadó

DOI: $10.34103 /$ ARGUMENTUM/2021/20

mondatok kiemelt szerkezeteiben egyfelől a tér két eleme (Pécs, Budapest) közötti képzeletbeli vonal hozzávetőleges hosszát adjuk meg, másfelől az idő lineáris vonalán elérésük időbeli hosszát.

A delativusi -ról, -ről irányjelölő értelmében a felületekről való lekerüléssel azonosítható (leszedte a tányérokat az asztalról), idő funkciójában ehhez hasonlóan a kétdimenziós időfelületekről történő lekerülést, azoktól való eltávolodást: ez a sütemény vasárnapról maradt. Noha használata ritkább, kérdőszava, a mikorról? azt mutatja, hogy az időbeli és helybéli eredetek közötti különbséget fontosnak tartjuk.

A mellettiséget kifejező adessivusi -nál, -nél angol megfelelöjéről, az at prepozícióról Radden azt írja, hogy pontszerünek, egydimenziósnak láttatja az adott időegységet: at this moment 'ebben a pillanatban'. Mint ahogy erről volt szó, a magyar megfelelöjét ihlető TARTÁLY metafora viszont határolttá és egyben háromdimenzióssá teszi az időegységet. Hozzáteszem, a magyar adessivusi rag időre vonatkozó előfordulása jóval ritkább, mint az angol at elöljáróé, lényegében metonimikus alakokban jelenhet meg az ugyancsak egydimenziós -kor helyén: ( $a$ vállalat alapitásánál $\approx$ alapitásakor. Kérdőszavuk is megegyezik: mikor? A hely- és időfunkciójuké ellenben elkülönül: hol? - mikor?

A hova? kérdésre válaszoló helyjelölő -hoz, -hez, -höz rag időfunkciójáról hasonlók mondhatók el, mint a már említett lativusi végződésekéről: főként az IDÖ MOZGÁs metaforához köthető kifejezésekben jelenik meg az igék vonzataként mint a mozgás végcélja a mozgó ego számára: lassan közeledünk a nyárhoz (bövebben 3.1 pont). Más a helyzet az ablativusi -tól, -töl raggal, amely hely értelmében valamely térbeli tárgy, entitás mellett, közelében lévő ponttól, a mozgást végző trajektor kiinduló pontjától való távolodást ad vissza: a busz az operától indul. A mikortól? kérdésekre felelve ennek a relációnak a cselekvés kezdőpontja felel meg, s nem kell hosszasan bizonygatnom, hogy a cselekvés kezdetének kifejezése fontos kommunikációs szükséglet: hétfötöl elkezdek dolgozni; holnaptól minden más lesz.

A térbeliséggel elsődlegesen kapcsolatba hozható említett 9 esetrag mellett felvettem a táblázatba az ugyancsak tér- és időkifejezésre alkalmas terminativusi ragot, amely mindkét funkciójában a határoltsággal hozható összefüggésbe. Egyikben a mozgások térbeli, illetve az események időbeli céljáról, végpontjáról referál: Sopronig utazom - 3-ig dolgozom. A másik szerepében az események időtartamát adja meg: két hétig nyaralunk. Olvasatomban mindkét elöfordulásában a FORRÁS - ÖSVÉNY - CÉL képiséma-metafora egy-egy elemére épül, az elsőben a cél, a másodikban a forrás- és célpontok közötti megteendő út kerül előtérbe. Kérdőszava: mennyi ideig? Az ösvény mint a cselekvés által megteendő út képe ott van az utóbbi idő jelentésével szinonim tárgyesetben: két hétig nyaraltunk - két hetet nyaraltunk. Az absztrahálódott tárgyeset viszont képes visszaadni a cselekvés térbeli útszakaszának teljesítését, amire az -ig nem alkalmas: 1 kilométert futott; *1kilométerig futott.

\begin{tabular}{|c|c|c|c|}
\hline kérdőszó & rag & térfunkció & időfunkció \\
\hline \multicolumn{4}{|c|}{ az irányhármasság ragjai } \\
\hline $\begin{array}{l}\text { hol? } \\
\text { mikor? }\end{array}$ & $\begin{array}{l}-b a n \\
\text {-ben }\end{array}$ & A lakásban több szoba van. & $\begin{array}{l}\text { 2021-ben remélhetöleg lesz az } \\
\text { olimpia. }\end{array}$ \\
\hline $\begin{array}{l}\text { hova? } \\
\text { hova? }\end{array}$ & $\begin{array}{l}-b a \\
-b e\end{array}$ & Belépett a szobába. & Beléptünk ez új évezredbe. \\
\hline $\begin{array}{l}\text { honnan? } \\
\text { honnan? }\end{array}$ & $\begin{array}{l}- \text {-ból } \\
\text {-böl }\end{array}$ & 7-kor kilépett az épületböl. & Ez a könyv a 18. századból való. \\
\hline $\begin{array}{l}\text { hol? } \\
\text { mikor? }\end{array}$ & $-n$ & Az asztalon könyvek vannak. & Kedden találkozunk. \\
\hline
\end{tabular}


Szili Katalin:

Az idö kifejezésének kérdéséhez a magyar nyelvben, különös tekintettel a tér és idö fogalmának összefüggésére Argumentum 17 (2021), 399-417

Debreceni Egyetemi Kiadó

DOI: $10.34103 /$ ARGUMENTUM/2021/20

\begin{tabular}{|c|c|c|c|}
\hline $\begin{array}{l}\text { hova? } \\
\text { milyen } \\
\text { távolságra? } \\
\text { mikorra? } \\
\text { mennyi időre? }\end{array}$ & $\begin{array}{l}-r a \\
-r e\end{array}$ & $\begin{array}{l}\text { János az asztalra tette a könyvet. } \\
\text { Szeged } 200 \text { km-re van Budapesttöl. }\end{array}$ & $\begin{array}{l}\text { 7-re otthon leszek. } \\
\text { Szeged } 2 \text { órára van Budapesttöl. }\end{array}$ \\
\hline $\begin{array}{l}\text { honnan? } \\
\text { mikorról? }\end{array}$ & $\begin{array}{l}\text {-ról, } \\
\text {-röl }\end{array}$ & $\begin{array}{l}\text { Anna leszedte a tányérokat az } \\
\text { asztalról. }\end{array}$ & Ez a bor tavalyról maradt. \\
\hline $\begin{array}{l}\text { hol? } \\
\text { mikor? }\end{array}$ & $\begin{array}{l}\text {-nál } \\
\text {-nél }\end{array}$ & Sokáig állt az ablaknál. & Nyári napnak alkonyulatánál... \\
\hline $\begin{array}{l}\text { hova? } \\
\text { mihez? }\end{array}$ & $\begin{array}{l}\text {-hoz, } \\
\text {-hez, -höz }\end{array}$ & Gyorsan odafutott az ablakhoz. & Lassan közeledünk a nyárhoz. \\
\hline $\begin{array}{l}\text { honnan? } \\
\text { mikortól? }\end{array}$ & -tól, -töl & Ellépett az ablaktól, hogy ne lássák. & Hétfötöl mindennap futni fogok. \\
\hline \multicolumn{4}{|c|}{ egyéb morfémák } \\
\hline $\begin{array}{l}\text { meddig? } \\
\text { meddig?/ } \\
\text { mennyi ideig? }\end{array}$ & $-i g$ & A Széll Kálmán térig utazom. & $\begin{array}{l}\text { 7-ig maradok. } \\
\text { Két napig maradok. }\end{array}$ \\
\hline $\begin{array}{l}\text { hogyan? } \\
\text { milyen } \\
\text { gyakran? }\end{array}$ & $\begin{array}{l}\text {-nként } \\
\text {-nta }\end{array}$ & Fejenként 1000 forintot kell fizetni. & $\begin{array}{l}\text { Esténként szívesen olvasok. } \\
\text { Nyaranta a Balatonnál pihenek. }\end{array}$ \\
\hline
\end{tabular}

1. táblázat. Tér-idö megfelelések az esetragok esetében

Szólnom kell még a táblázat utolsó eleméről, az ugyancsak kettős funkciójú distributivusi morfémáról, amelynek létezik a térbeliséghez köthető ismétlődő-elosztó tartalma: családonként 1000 forintot kell fizetni - vasárnaponként meglátogatta a szüleit. Emellett van a magyarban egy kizárólagos distributiv temporalisi morféma, a -nta, -nte: nyaranta, telente, évente. A két elem szinonimaként történő használata meglehetősen szövevényes, talán egyetlen szabályt tudunk megfogalmazni: a temporalisi morféma nem alkalmas térbeliség megjelenítésére, viszont a térbeli distributivusi alak jelölhet időbeli ismétlődést: * családonta 1000 forintot kell fizetni nyaranként/nyaranta a Balatonnál találkozunk; hetenként/hetente kétszer futok. Mindez egyrészt a térfunkció korábbi kialakulását, elődlegességét igazolja, másrészt az időkifejező tartalom későbbi önállósodását, előtérbe kerülését amazzal szemben (lásd az eltérő kérdőszókat az 1. táblázatban).

Összegezve a térhez köthető esetragoknak az idő kifejezésében betöltött metaforikus szerepét, a következőket állapíthatjuk meg: a helyek és irányok tapasztalati elsőbbsége nem vonja maga után az időfogalom másodlagosságát, az időbeliség éppen olyan összetett rendszert alkot, mint a térbeliség. Az időjelentések függetlenedése - aminek érzékeny mérője az időre vonatkozó kérdőszók megléte vagy hiánya - a kommunikációs szükségletekkel összefüggő fokozatokat mutat: a) a lativusi vonzattal álló igék esetében (átléptünk a 21. századba; visszamegyünk a középkorba) egyszerü metaforikus kiterjesztésröl beszélhetünk, a két morféma teljes funkcionális elkülönülése nem történt meg, amit a közös kérdőszavaik is jeleznek (lásd hova?, honnan? kérdéseket az 1. táblázatban); b) a rag időjelentése a térrel összefüggő jegyekből konstruálódik, de funkcionálisan független, amit kérdőszava is megerösít (lásd az 1. táblázat félkövér kiemeléseit); c) a tér - idő megfelelés áttételes, a raghoz olyan időjelentés társul, aminek nincs térbeli változata. Ez az időtartamot kifejező sublativusi - $r a$, -re és az azonos szerepü terminativusi -ig ragokról mondható el. 
Szili Katalin:

Az idö kifejezésének kérdéséhez a magyar nyelvben, különös tekintettel a tér és idö fogalmának összefüggésére Argumentum 17 (2021), 399-417

Debreceni Egyetemi Kiadó

DOI: $10.34103 /$ ARGUMENTUM/2021/20

\subsection{Az idö horizontális, vertikális felfogását tükrözö nyelvi eszközök}

A három geometriai axis közül a nyugati kultúrák időkoncepciójában dominánsan a horizontális van jelen, így a magyarban is, szemben az ázsiai nyelvekben, így a kínai mandarinban meglévő vertikális elképzeléssel. „Az arccal a jövő felé” pozíció megfelel a térben való elhelyezkedésünknek, mozgásunknak, amelynek lényegi és a fizikai adottságainkból következő tapasztalása az, hogy úgy célszerü haladnunk egy képzeletbeli horizontális vonal mentén, hogy a tárgyak, dolgok a szemünk előtt legyenek, ebböl következően amikor elhagyjuk őket, a hátunk mögé kerülnek, a nem láthatóság körébe vesznek.

\subsubsection{A névutók}

A horizontális időképet tükröző főbb lexikai elemek a névutók, így mindenképpen ki kell térnünk esetükben is a tér - idő koncepciók közötti áthallásokra, különbségekre, esetleges eltérő mértékü elkülönülésekre. Ez jelen esetben a háromdimenziós térben fellelhető entitások egymáshoz képest tapasztalható pozícióinak és az idő lineáris síkjára képzelt pontszerü, illetve kiterjedt, időtartammal bíró eseményeknek szekvenciális, egymáshoz viszonyított meghatározását jelenti. A szóba jöhető névutók közül leterheltségük okán nyolcat, az elött, mögött, után, között, körül, felé, alatt, vmin belül formákat állítottam az elemzés középpontjába.

Kezdjük a leírást a horizontális időkép legegyértelmübb tükrözőivel, az elött, mögött, után névutókkal! Az elött - az etimológiájának megfelelöen - a testeknek valós vagy a beszélö perspektívájából adódó elülső részét adja meg referenciapontként, a mögött pedig az ezzel ellentétes oldalát: János az opera elött várja Annát; Az étterem az opera mögött található. Az elött térbeliségben mutatott jegyei változtatás nélkül képződnek le az idő kifejezésekor: még nehéz napok állnak elöttünk. A mögött-ről ugyanez csak megszorításokkal mondható el, egyfelöl azért, mert a közvetlen megfelelés a kétféle használata között csak élö referenciapontokra vonatkoztatható, eseményekre nem: Magunk mögött hagytuk a nehézségeket; János maga mögött hagyta életének ezt a szakaszát; *Az ebéd mögött kezdödik az elöadás. A szóban forgó kifejezések az IDŐ MOZGÁs metafora MOZGÓ EGO változatát képviselik (lásd 3.1 pont). Az események egymásra következését viszont egy másik elem, a mai magyar nyelvben csak idő szereppel rendelkező után jelöli: a beszélgetés után mindenki megnyugodott; az elöadás után beültek egy kávéra. Ez igaz az utánam következel típusú elliptikus szintagmákra is, ahol a birtokos személyjeles névutó valójában az elkövetkezö cselekvésre vonatkozik. A mögött, után névutók funkcionális elkülönülése, de leginkább az után kialakulásának története igencsak hasznos adalékokkal szolgál a tér - idő viszonyához, mivel azokat a véleményeket erösíti, amelyek szerint a tér fogalma idő faktorokat is magába foglalhat, ahogy az idö térelemeket is tartalmazhat (lásd Stocker téridő fogalmát, 2014). Az Etimológiai szótár szócikke szerint ugyanis a nyelvünkben 1372 utánra datált ragos főnévből névutóvá lett forma tulajdonképpen az út fönév egyes szám 3. személyü birtokos személyjeles és - $n$ superessivusi alakja, ami „Eredetileg konkrét helyi, 'valakinek az útján' jelentésü fónév volt” (Zaicz 2006: 777). A valakinek az útján, nyomában járás pedig magában hordozza az időbeli fáziskésést, tehát a térbeliség és időbeliség egyidejüleg van jelen benne. A téridő fogalma mellett érvelő idézett tanulmányában Kurt Stocker az angol after-nél fedezett fel hasonló történeti átalakulást. A ma már csak idöjelölö after a régi angolban kétféle értelemben volt használatos: Az After whom rode on horse back a Courier of the Republick „Aki után lovagolt a köztársaság futára” mondatban helyre utal, a They are not good to be taken after meat „a hús után nem jó bevenni öket” prepozíciója pedig időre (Stocker 2014: 10). Hasonló jelenségre több forrásra hivatkozva lexikai példát is 
említ, a follow „követ” szót (i. m. 11). A New Year's follows Christmas mondatban a követő, azaz az újév, a követett, a karácsony „mögött” helyezkedik el időben (i. m. 11), ahogy A kutya követi Pétert mondatban a kutya megy Péter nyomában. Hozzáteszem, a magyarban létezik az ige idő értelmü visszaható változata, a következik: a fóétel után következik a desszert.

Továbblépve a névutók sorában, a kétféle között teljes egyezését elég csak illusztrálni: $A$ lámpa az asztal és a szék között van. - Találkozzunk 7 és $8 \boldsymbol{k o ̈ z o ̈ t t . ~ A z ~ e l s o ̋ ~ e s e t b e n ~ a ~ l a ́ m p a ~ a ~}$ két megnevezett tárgy közötti tér önmaga által kijelölt szegmensét foglalja el, a másodikban ugyanezt teszi a találkozás a két időpont közötti időszakasszal. A körül valamely térbeli test minden oldala (elülső, hátulsó, oldalsó) körüli elhelyezkedés fejez ki, ezzel szemben idöre vonatkoztatva (lásd lineáris idővonal) leszűkül a tartalma két helyzetre, az idővonalon balról jobbra haladó eseményt megelőző és az azt követő időszakaszra: a ház körül fák nőnek: hét óra körül találkozunk. A körülbelüliség a közös szemantikai eleme a felé kétféle használatának, de a különbség, az elkülönülés nyoma is felfedezhető köztük: Buda felé jössz te is?; Hét felé találkozunk. Míg az első mondat irány értelmű névutós szerkezete a mozgás hozzávetőleges célját adja meg, addig a második időhatározója a célidő előtti és utáni időszakaszt is magába foglalja, amit az is alátámaszt, hogy helyettesíthető a körül névutóval: 7 felé/körül találkozunk. A szinonimáknál maradva, ki kell térnem a körül, felé használatával megegyező tájban/tájt formákra, amelyek - különösképpen az inessivusi alak - tartalmukban, de morfológiai felépítésükben is őrzik a térrel való szoros kapcsolatukat, ahogy a részletezést nem kívánó vmin belül névutós szerkezet ugyancsak: a távolugró vonalon belül maradt; két napon belül végzek a munkával.

\subsubsection{Egy kis kitérõ: vertikális időorientáció a magyar nyelvben? Az alatt névutó és a le-, fel- igekötök}

A vertikális axishoz a térben két névutó, a fölött és alatt köthetö: a lámpa az asztal fölött van; a macska a szék alatt ül. A fölött nem fejez ki időt a magyarban a horizontális időorientációból adódóan, annál meglepőbb, hogy az alatt-nak kialakult időszakaszt jelölő tartalma. Az térbeli és időbeli jelentéseinek megfelelése, eltérése bővebb kifejtést igényel. Járjunk tehát utána, milyen jegyek kerülhettek át a macska az asztal alatt ül szintagma térjelentéséböl az Anna a film alatt kötött egy pulóvert szerkezetébe! A közös pontokat, amelyek az időfunkció kialakulásához vezettek, a következőkben látom: az alatt - mintegy a superessivusi -on ellentettjeként - két dolog érintkezést mellőző, közel azonos helyzetét tükrözi egy képzeletbeli vertikális tengely mentén, ahol az egyik entitás a fenti, a másik a lenti pozíciót foglalja el. Az azonos referenciális és eseményidők esetén a relációk a következő módon alakulnak: a „fölött” pozíciót az időintervallum foglalja el, amelynek kifejezője lehet egy történést kifejező fönév (film, magyaróra, előadás stb.) vagy egy számjelzővel megadott időtartam (két év), az ,,alatt” helyzetbe pedig a végbemenő események, cselekvések kerülnek. Az alatt taglalt funkcióját a 2. ábra mutatja be. 
Szili Katalin:

Az idö kifejezésének kérdéséhez a magyar nyelvben, különös tekintettel a tér és idö fogalmának összefüggésére Argumentum 17 (2021), 399-417

Debreceni Egyetemi Kiadó

DOI: $10.34103 /$ ARGUMENTUM/2021/20

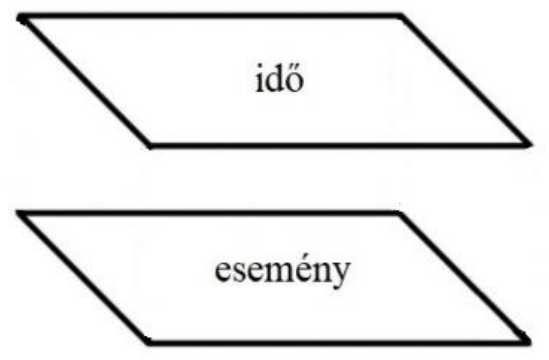

2. ábra. Az alatt időfunkciójának képe

Aspektuális jellemzőiket tekintve kétféle helyzettel van dolgunk: a számjelzős szintagma a pontos ,időfelületet” szabja meg, amelynek fednie kell az esemény megvalósulásának idejét: két óra alatt megkötött egy pulóvert. A főneves konstrukciók időszakasza folyamatban levő és megvalósult eseményekre egyaránt vonatkozhat: az óra alatt olvasott; az óra alatt elolvasott egy novellát.

A fenti ábrával jól szemléltethető az angol over és a magyar alatt ellentétes idő - esemény perspektívája. Az Over the last year and a half we have improved market position „az utóbbi másfél év alatt javítottuk a piaci pozíciókat" mondatban az esemény helyezkedik el az időtartam fölött, a magyarban pedig fordítva, az esemény kerül az időszakasz alá.

A fent-lent helyzetekkel operáló vertikális időorientáció, miképpen említettem, az ázsiai kultúrákra, nyelvekre jellemző. Radden ugyanakkor Traugottra hivatkozva (Traugott 1975: 222) említ angol igéket, amelyek azt mutatják, hogy ha nem is rendszerszerüen, de vannak nyomok a vertikális időszemléletre: a The tradition lasted down through the centuries „A tradíciók az évszázadokon keresztül fennmaradtak" mondat igéjének down „le” eleme magyarázatában azt sugallja, hogy az idő, amíg a tradíció él, lent van, az előző idők, vagyis a kezdet pedig fenn, tehát az esemény iránya fentről, a múltból lefelé, a jelenre irányul (Radden 2011: 8). A last down magyar fordítása mellett nem mehetünk el említetlenül, mivel a magyarban éppen hogy a fenn helyzettel adható vissza: fennmarad. Az ok az eltérő orientációs metaforák alkalmazásában rejlik, és igazolja azt a meggyőződésemet, hogy a konceptualizációs folyamatok nyelvileg is determináltak, vagyis nem függetleníthetők a figuratív nyelvhasználat egyéb elemeitől. A fenn, fel- általában a láthatóság, észlelés a megfoghatóság, a létezés képzetével társul a magyarban, amit nemcsak a fenn- előtagú igék igazolnak (fennáll, fennforog, fennmarad, fenntart), de a fel- igekötős igék hasonló jelentésủ homogén csoportjai, amelyekben még ott van az eredeti, 'mélyből a felszín felé' irányuló mozgás. A mélységet az ájultság, eszméletvesztés, a nyugalmi állapot képviseli az alábbi igékben, a fenn pedig az éber állapotot: feléled, feléleszt, feleszmél, felocsúdik, feldörzsöl, felérez, fellocsol, feltámad, feltámaszt. A következő igekötős igékben a lentről felfelé irányulás az ismeretlenségből, a nemlétből (a múltból) az ismertségbe, létezésbe (a jelenbe) vezető utat testesíti meg: felbukkan, felcsillan, felemleget, felemlit, felhajt, felhánytorgat, felidéz, feljön, felkel, felködlik, felmerül, felötlik, felpiszkál, felrémlik, feltetszik, feltünik, felvetödik, felvirrad. Rokon kognitív csatolásokat idéz Radden is (2011: 9). Szerinte a My birthday is coming up mondat igéjének partikulája azt a képzetet kelti, hogy az alany, a születésnap valahonnan a múlt mélyéből jön elö, de ugyanez történik a pop up „felbukkan”, turn up „előkerül” igékben, amelyek azt sugallják, hogy a felfelé irányuló perspektíva valamilyen új keletkezésével jár együtt. Itt hivatkozik a Benczes Réka által szolgáltatott magyar adatra, amely az ellentétes irányt kifejező le- hasonló szerepét támasztja alá: Tegnap 
Szili Katalin:

Az idö kifejezésének kérdéséhez a magyar nyelvben, különös tekintettel a tér és idö fogalmának összefüggésére Argumentum 17 (2021), 399-417

Debreceni Egyetemi Kiadó

DOI: $10.34103 /$ ARGUMENTUM/2021/20

lement a vizsga. Értelmezésében a lemegy különféle tervezett eseményekkel (mozi, előadás, vizsga stb.) kapcsolatban fordul elő, és lényegében két időfogalmat egyesít: egy korábbi időt, amikor is a tervezés történt, és egyet, amelyben megvalósul. Az utóbbi, vagyis a realizáció mint $l e$ - jelenik meg, a tervezés szakasza pedig mint fenn, a vertikális időorientációnak megfelelően (i. m. 11). Okfejtéséhez mindenképpen kívánkozik néhány kiegészítés, módosítás. Először is a jelenség nem függetleníthető a le- telicizáló, ha tetszik perfektiváló tulajdonságától (Szili 2006), amely tucatnyi, nem csak ,tervezett esemény” értelmü alannyal előforduló igében van jelen: lebonyolit, lebonyolódik, leél, lefolyik, lefolytat, leforog, lefut, lejár, lejátszik, lejátszódik, leküzd, lemegy, lemorzsol, leöröl, lepereg, leperget, lesétál, leszolgál, letelik, letud, letünik, leül, levizsgázik, levizsgáztat, lezajlik, lezúg, levan.

Ha végigtekintünk az elöbbi listán, igazolva látjuk azt az állítást, hogy a telikus funkcióban sem beszélhetünk az irányjelentés teljes kiüresedésröl, a le-eredeti irányjelentése részét képezi azoknak a mindennapi eseményeknek, tevékenységeknek, amelyek alapul szolgáltak a cselekvésidő és általában az idő múlásának a LE képi sémához kötéséhez. Gondolok a hegyről induló patak vízének folyására (a sok víz folyik le a Dunán addig), a rokkáról lepörgő fonálra avagy a malomban a garaton lefelé mozgó búzára, ahol a trajektorok lefelé történő mozgásának vége az események célhoz érésével, befejezésével egyenlő: lefolyik, leöröl, ledarál, lemorzsol, lepereg. Az előbbi képek alapján az idézett igecsoport több tagját azonosíthatjuk akár a KEVESEBB LEFELÉ IRÁNYULTSÁG, A TÖBB FELFELÉ IRÁNYULTSÁG orientációs metaforával is: $a$ leüli/leszolgálja az idejét igéiben a múlt, a FENT állapot, amelyhez viszonyítva a szolgálat ideje egyre csökken. Ilyenek még: leél, lejár, letelik, lesétál, valamint a lemorzsol, leöröl, lepereg metaforikus jelentései. De ugyanígy értelmezhetôk az ÖSVÉNY képi sémával: a lesétálta a két órát, ledolgozta a 8 órát szintagmákban a tárgyak nevezik meg a cselekvések által bejárandó utat (ösvényt), az igekötős ige pedig a végpont elérését, következésképpen a le- helyettesíthetö a végig elemmel: ledolgozta a 8 órát - végigdolgozta a 8 órát.

Az igekötős igék fentiekben érintett jellemzőit én az aspektus, azon belül is a végpontosság, behatároltság fogalmához kötöm, ami vitathatatlanul hozzátartozik az idő fogalmához, de leírása a jelen dolgozatétól eltérő megközelítést kíván.

\section{$3 \quad$ Az idő fogalmi metaforái a magyar nyelvben}

A fejezetben az elméleti bevezetőben vázoltaknak megfelelően a három fő tapasztalati körhöz, a térhez, térbeli relációkhoz, a tartály fogalmához, valamint az eseményekhez köthető metaforákon keresztül vizsgálom az időkoncepció részét képező alábbi jegyeket: 1. múlását, 2. intervallumokra való feloszthatóságát, 3 . az eseményeknek színteret adó képességét, 4 . mérhetőségét, 5. szociokulturális értékeit.

\subsection{Az idõ múlása: AZ IDŐ TÉR generikus metafora megnyilvánulásai}

Az idő, mint arról már volt szó, nagyrészt a tér konkrét tartományában, az IDŐ TÉR generikus szintü metaforán keresztül konceptualizálódik (Lakoff \& Johnson 1999: 52). Mivel a generikus metaforák túl általános forrástartománnyal bírnak, jelen esetben a tér fogalmával, több specifikus szintü képben nyilvánulnak meg. Nézzük ezeket fontosságuk feltételezett sorrendjében!

A térnek meghatározó eleme a mozgás, a mozgás időbe helyezése pedig az utóbbi fogalom bennünket érdeklő tulajdonságának, a múlásának kifejezésében nyer jelentőséget. AZ IDŐ 
Szili Katalin:

Az idö kifejezésének kérdéséhez a magyar nyelvben, különös tekintettel a tér és idö fogalmának összefüggésére Argumentum 17 (2021), 399-417

Debreceni Egyetemi Kiadó

DOI: $10.34103 /$ ARGUMENTUM/2021/20

MOZGÁS (TIME AS A MOTION) strukturális metaforának többféle sémáját ismeri a szakirodalom. Clark szerint (1973) kétféle helyzet lehetséges: vagy egy esemény mozog a tapasztaló személy „most'-ja felé az idővonalon, vagy a tapasztaló mozog egy időbeli határpont felé. Az előbbit szokásos MOZGÓ IDŐ (MOVING TIME), az utóbbit MOZGÓ EGO (MOVING EGO) metaforaként is számon tartani: közeledik a tavasz; közeledünk a tavasz felé. Ugyanezt Lakoffnál a mozgás és az idő múlásának elválaszthatatlanságát hangsúlyozó, AZ IDŐ MÚLÁSA MOZGÁS (TIME PASSING IS MOTION ) metafora foglalja magába, amelynek szintén két hasonlóan megfogalmazott konceptualizációját különíti el az angolból kiindulva (Lakoff 1993, 1994). AZ IDÖ MÚLÁSA MOZGÓ TÁRGY (TIME PASSING IS A MOVING OBJECT) metafora alapján statikus helyzetben képzeljük el magunkat, a jövőből felénk közelítő események pedig keresztülmennek rajtunk, aztán elvonulnak a múltba: jön a húsvét. AZ IDÖ MÚLÁSA MOZGÁS EGY TÁJON KERESZTÜL (TIME PASSING IS A MOTION OVER A LANDSCAPE) (Lakoff \& Johnson, 1999: 141-144) metaforában az idő múlása úgy jelenítődik meg, hogy az ego is mozog a rögzített, mozdulatlan tájban, maga után hagyva, teljesítve az egyes időegységeket: közeledünk a húsvét felé. Ahrens és Huang (2002) Yura (1998) hivatkozva megjegyzik, hogy az európai és ázsiai időorientáció eltérése miatt míg az elöbbiben a megnyilatkozó szemben áll a jövővel, vagyis a jövő felé orientálódik, az ázsiaiban az ego a múlttal szembesül és nem a jövővel: a kínai mandarinban a shang „fent, fel” elem megjelenése az igék előtt a múltbéli eseményekre utal, xia „lent, le” pedig jövőbeliekre.

Ahogy az eddigi példamondatok mutatják, a magyarban egyértelműen létezik AZ IDŐ TÉR metafora, ahogy megvannak az iménti specifikus változatai, de az is nyelvi adatok hosszú sorával támasztható alá, hogy a mozgás mozzanatához metaforikus, egészen pontosan meg személyesítést tartalmazó kifejezések járulhatnak, amelyekben a mozgásokat a lineáris-horizontális idősík-elképzelésünknek megfelelő helyváltoztató igék képviselik (megy, jön, szalad, folyik, rohan, cammog, halad, száguld, repül), és nem a vertikális fel-le irányokhoz rendelhetők: felmegy, feljön, ugrik, felszökken. A megszemélyesítés, ahogy Lakoff és Turner (1989: 72) hangsúlyozzák, kiváló eszköz arra, hogy az önmagunkról való tudásunkat mozgósítsuk arra, hogy megértsünk a természetet, az élettelen dolgokat, az absztrakt fogalmakat. A megszemélyesítésben a mozgást végző idő emberi entitásként mozog, sőt a cammog, repül azt jelzi, hogy az állatok mozgását szintén utánozhatja (a megszemélyesítésről lásd még Lakoff \& Johnson 1980: 33-34).

A magyar nyelvben a vektor tulajdonságú igekötők és a mozgásigék együttesei ugyancsak gazdag tárházául szolgálnak a térbeli mozgások és az idő múlásának összekapcsolódására. Közülük is kiemelendők az egy pontból való távolodást kifejező el-igekötővel létrehozott alakok, amelyek AZ IDŐ MÚLÁSA TÁVOLODÁs metaforára füzhetők fel: az idő elcsúszik, elfolyik, elfut, elhalad, elillan, eliramlik, eljár, elmegy, elrepül, elrohan, elröppen, elsuhan, elszalad, elszáll, elúszik. Kiemelném közülük A magyar nyelv értelmező szótárában még szereplő, a mai nyelvből kiveszett elcsúszik alakot: Ne hadd elcsúszni a jelent! (ÉrtSz. 1960: II. 111).

Az emberként mozgó, viselkedő idő képéből kiindulva szokásos elkülöníteni AZ IDÖ SZEMÉLY (TIME AS A PERSON) metaforát. Sondes Hamdi doktori disszertációjában (Sondes 2008) szótárakra, újságokra és irodalmi szövegekre támaszkodva 22 angol és 17 arab ilyen kifejezést tudott azonosítani korpuszában. A hasonló gyűjtés még várat magára a magyar nyelvben, de az eszünkbe jutó példák sokasága alapján bizton állíthatjuk, hogy van miből válogatnunk: ez az év nem hozta el, amit vártunk töle; az évek megtanitottak arra, hogy; majd az idő eldönti; az idö begyógyítja a sebeket; az idö mindent megold/kiderit; az idö nekünk dolgozik; az idö vas foga szétrágta; a legjobb orvos/gazda az idö. Ezekben a kifejezésekben az idő tanító, gyógyító, megoldó, jótevő személyként vagy éppen ellenségként, megsemmisítőként, pusztítóként, tolvajként 
Szili Katalin:

Az idö kifejezésének kérdéséhez a magyar nyelvben, különös tekintettel a tér és idö fogalmának összefüggésére Argumentum 17 (2021), 399-417

Debreceni Egyetemi Kiadó

DOI: 10.34103/ARGUMENTUM/2021/20

tevékenykedik. Kövecses Zoltán még tágabb összefüggésbe helyezi ezt a megszemélyesítésfajtát, szerinte ugyanis a speciális ágensi jegyeket annak köszönhetően veheti fel, hogy kapcsolatban van más, az időt közvetve magukban foglaló szóképekkel, így az élet és halál metaforáival (2010: 55). Utóbbiakban nyilvánvalóan negatív figuraként szerepel.

\subsubsection{Az idõ múlása: AZ IDÖ FOLYÓ; AZ IDÖ FOLYÁSA A CSELEKVÉS FOLYÁSA metaforák}

Az idő múlásának a folyó vízzel való azonosítása - mint közös ősi élményünk - elég elterjedt a nyelvekben. AZ IDŐ FOLYÓ metaforáról több tanulmány is született (Smart, 1949; Freeman 2004). Utóbbi azért érdemel figyelmet, mert kitágítja a Lakoff és Johnson 1999-es írásában olvasható értelmezést. Ez úgy írja le a szóban forgó képet, hogy a szemlélő a folyásiránnyal szemben helyezkedik el, így a víz a múlt felé mozog (MOZGÓ TÁRGY). Freeman viszont felhívja a figyelmet Merleau-Ponty 1962-es tanulmányának két másik lehetséges magyarázatára: az egyikben a szemlélő a folyás irányával megegyezően helyezkedik el, ekkor az idő a jövő felé mozog, a másikban pedig együtt mozog a vízzel (mondjuk, csónakban vagy úszva) a mozdulatlan tájban. A víz folyásához, az áramláshoz köthető metaforikus kifejezéseket találunk a magyarban is: az idö elsodorta öket egymástól; az idö sodrásában megfeledkeztem róla; úszunk az idővel, elúsztunk a határidővel stb.

AZ IDŐ MOZGÁs kép kapcsán korábban említettem, hogy az idő múlását visszaadhatjuk a folyó fönév igei tövével is: lassan folyik az idö; gyorsan elfolyt az idő. Tovább idézve a gazdag szócsalád tagjait, az éppen aktuális évet, hónapot folyó jelzővel illetjük: folyó év, folyó hónap. A melléknévi igenévi forma önkéntelenül is felidézi a szürrealista katalán-spanyol festő, Salvador Dalí Az emlékezet állandósága (Persistencia de la memoria) címü, elfolyó órákat ábrázoló festményét, amelyen az idő képlékennyé vált tárgyi szimbólumai figyelmeztetnek a tér és az idő viszonylagosságára. Továbblépve a szócsalád következő motivált tagjára, a folyamat szóra, amelyet valamely esemény menetével, múlásával összefüggésben használunk: ez a dolgok természetes folyamata; az ügy folyamatban van. Az utóbbi példák jól érzékeltetik, hogy az idő múlása nem választható el az események menetétől, lefolyásától, ami AZ IDŐ FOLYÁSA AZ ESEMÉNY FOLYÁSA metafora létét támasztja alá. Még egyértelmübb bizonyíték erre a vmi folyamán, amelynek fejlödéstörténete lényeges összefüggésekre derít fényt. Mindenekelőtt nézzük a folyam relatív tövet, amelynek A magyar nyelv értelmező szótára még ismeri a magát a cselekvést megnevező „áradat, áramlás”, illetve „lefolyás” értelmét: ... a föld alatti víz, melynek zuhogó folyamában kellett gázolnia (ÉrtSz. II. 867), sőt - ami számunkra meghatározóbb találunk idézetet az esemény időbeli áramlásával (folyásával) azonos alatt névutós szerkezetre: az ütközet folyama alatt Isaszeget is felgyújtották (uo., kiemelés tőlem, Sz. K.). A Magyar történeti szövegtár adatainak tanúsága szerint a 19. században még aktív szerkezet mára kiszorult a nyelvhasználatból, a 20. századtól átvette helyét a szó birtokos személyjeles és - $n$ ragos változata, a folyamán. Használata AZ IDŐ FOLYÓ kép idézett három olvasatából a másodikkal és harmadikkal egyaránt rokonítható, vagyis a referáló aspektusa a múltból a jövőbe mutathat ( $a z$ idők folyamán megváltozott a véleménye), de az esemény és a megadott időszakasz egybe is eshet: a délelött folyamán tárgyaltak. Ahogy a régies folyama alatt világosan jelzi, az esemény lefolyásával, tartamával azonosítható funkciója közel áll a vertikális időorientációnál tárgyalt alatt névutóéval (2.2.2 alpont). De a során ragos fönévével is, amelynek alapszava, a sor tárgyak, személyek egyvonalban történő vagy egymás mögötti elrendeződését foglalja magába a térben: a székeket sorba rakta. Idő értelmében éppen ezért egyfelöl az események részmozzanatokból összeálló folyamatát jelöli, ezért is helyettesíthető az alatt névutóval és a közben név- 
Szili Katalin:

Az idö kifejezésének kérdéséhez a magyar nyelvben, különös tekintettel a tér és idö fogalmának összefüggésére Argumentum 17 (2021), 399-417

Debreceni Egyetemi Kiadó

DOI: 10.34103/ARGUMENTUM/2021/20

utószerü ragos formával: a beszélgetés során/alatt/közben nem érintettek kényes témákat. Másfelől a múltból a jövőbe mutató szerepében a többes számú főneveknek köszönhetően szek venciális tartalommal gazdagodik: az események során többször korrekcióra kényszerültek.

\subsection{Az idö intervallumokra történö feloszthatósága: a FORRÁS-ÖSVÉNY-CÉL képi sémák}

Elöljáróban meg kell jegyeznem, hogy az elöbbi jeggyel szorosan összefüggő vonással van dolgunk, de itt inkább az idő vagy az esemény által „,megtett útra”, másképpen fogalmazva az eltelt intervallumra helyeződik a hangsúly a konceptualizáció során. Ez megtörténhet AZ IDŐ MÚLÁSA MOZGÁS EGY ÖSVÉNY MENTÉN metaforával, amely a FORRÁS-ÖSVÉNY-CÉL képi séma középső eleméből táplálkozik. Ebben az esetben az idő a trajektor, amely mozog egy úton mindaddig, amíg a szituációbeli esemény el nem ér a végéig: sok idö ment el az épitkezés befejezéséig.

A FORRÁS-ÖSVÉNY-CÉL hármas sémából az utóbbi kettőből építkezik AZ IDŐ MÚLÁSA AZ ESEMÉNY ÁLTAL VÉGIGJÁRT ÖSVÉNY metafora, amely az előbbi kép tágabb, minden eseményre vonatkoztatott variációja. Az idő mint tapasztalat események, cselekvések tulajdonságaiból is összeállhat. Az eseményeknek, akár a mozgásoknak, két érzékelhető jegyük van, időbeli kiterjedésük, azaz tartamuk, illetve egymás utániságuk, szekvenciális rendjük. A köztük és a térbeli pozíciók közötti hasonlóságokat Sinha és Bernárdez a következőkképpen írják le: az események bizonyos szempontból olyanok, mint a tárgyak, de különböznek is tölük. A tárgyak a térben vannak, noha időlegesen, de ottmaradnak, tömeggel és energiával rendelkeznek. Az események az időben helyezkednek el, ,elfoglalják” azt, mint a tárgyak a helyüket, következésképp pozícióik alkalmasak arra, hogy elhelyezzük magunkat az időben, ahogy a tárgyak is segítik a térben való tájékozódást (lásd a névutókról szóló 2.2.1 alpontot): a munka elött pihent egy kicsit; az Opera elött várlak. Birth (2012) az események orientáló szerepét olyannyira fontosnak tartja, hogy a kronológiai mellett elkülönít ún. eseményalapú időintervallum felosztást, amelyben az időt az események sora alkotja, határaikat pedig kezdő- és végpontjaik szabják meg, következésképpen az idő és az esemény szóban forgó szakaszai egybeesnek. Az esemény alapú időintervallum lehet nála állapotváltozás (napfelkelte - napfelkeltekor induljunk), statikus eseményattribútum (világos - igyekezzünk, hogy világosban érjünk haza), metonimikus lexikalizáció eredménye: aratás - aratáskor született.

A térbeli távolságok kezdő- és végpontjának érzékelése által előidézett szerkezeti párhuzamok az eseményintervallumok kijelölésében, kezdő- és végpontjuk jelzésében is tetten érhetők: a házuktól a parkig futott $\rightarrow$ végigfutotta a házuktól a parkig vezetö utat-Este 8-tól reggel 6ig táncolt $\rightarrow$ végigtáncolta az éjszakát. Az időbeli végpont elérésének kifejezésére nemcsak a végig igekötőszerủ elem szolgál, hanem az át- igekötő is, amely időhasználatában némi átalakuláson megy keresztül. Az át- a térben két átellenben levő hely esetében az egyikből a másikba történő eljutást fejez ki: Délután átugrom hozzátok; A pirosnál átment az úton. Az át- az első mondatban utalhat a megnyilatkozó lakásával vagy házával szembeni lakásra, a másodikban az út másik oldalára. Időfunkcióban a végig- használatával lineáris síkra vetítődik a szituáció, és a tárgy vagy alany egy behatárolt szakaszt metsz ki az idő vonalából, amit a predikátumokba foglalt cselekvések végigjárnak: a végigalussza az éjszakát, végigbeszéltük az estét. Az át- igekötős szintagmában ellenben az időintervallumot megtestesítő elemek testtartállyá válnak, amelyen „keresztülmegy” az állítmányba foglalt cselekvés: átalussza az éjszakát, átbeszéltük az estét. A szóban forgó tartalom többek között az alábbi igékben található meg: átvészel, átmegy, 
Szili Katalin:

Az idö kifejezésének kérdéséhez a magyar nyelvben, különös tekintettel a tér és idö fogalmának összefüggésére Argumentum 17 (2021), 399-417

Debreceni Egyetemi Kiadó

DOI: $10.34103 /$ ARGUMENTUM/2021/20

átél, áttelel. Az utóbbi származék metonimikus volta miatt érdemel figyelmet: IDÖINTERVALLUM A CSELEKVÉS HELYETT.

\subsection{Az idö mint azt események „helye”, AZ IDÖ TARTÁLY metafora}

Az idő tartályként való konceptualizációjára, AZ IDŐ TARTÁLY metaforára már hivatkoztam a morfológiai eszközök taglalásakor. A TARTÁLY ontológiai metafora ihlető képi sémaként jelen van az eseményekkel kapcsolatos strukturális metaforákban is. A tartály háromdimenziós, térbeli kiterjedéssel bíró test, amelynek két vagy három oldalról körülhatárolt belső tere van, tehát BENT - KINT helyviszonyokat hoz létre. Ez a több irányú határoltság, valamint a szabad „belső” tér képződik le az idő céltartományban, ahol az események, cselekvések úgy foglalnak helyet, ahogy a szoba terében a bútorok: a szobában bútorok vannak. - Ebben az évben elöször leteszem a vizsgáimat, utána munkát keresek. A TARTÁLY metaforával az eseményeket határok között, azokon belül tarthatjuk: idöben megirtam a cikket. Ha a csapatunk idön belül dobott gólt, örülhetünk, ha idön kívül, bosszankodhatunk, de ki is léphetünk képzeletbeli határaiból: kifutott az égö házból - kifutott az időböl.

Ismételten az igekötős igék tárgyában végzett kutatásaimban (Szili 2003) találtam lexikai bizonyítékokat A CSELEKVÉSEK TÁRGYAK, AMELYEK KITÖLTIK AZ IDÖTARTÁLYT metafora meglétére, amit a Heine, Claudi és Hünnemeyer szerzőhármastól (1991) kölcsönöztem. A kiigekötős igék között létezik ugyanis egy kisebb tömörülés, amelyben az igekötő funkciója így fogalmazható meg: ,az alapigében kifejezett cselekvést a grammatikai tárgyban meghatározott ideig végzi”. Ez közel áll az előző, AZ IDŐ MÚLÁSA AZ ESEMÉNY ÁLTAL VÉGIGJÁRT ÖSVÉNY képhez, de mivel a $k i$ - eredeti irányfunkciója tartályszerü testekből való kijutást jelenít meg, a perfektivitással azonosítható jelen változatában is a határokon belül maradás, a BENT-böl, azaz a középpontból a test határáig terjedő ráhatás mozzanata hangsúlyozódik: kifestette a szobát, kiszinezte a képet. A kiszolgálta a katonaidejét szintagmában a „katonaidő” az az időtartály, amelyet az ágens a megnevezett cselekvéssel teljesen betölt. Még egyértelmübb a tartálymetafora az alapigének köszönhetően a kitölt, kitelik esetében: kitöltötte a katonaidejét; kitelt az ideje. A hasonló szerepü ki- igekötős igék AZ IDŐ MÚLÁSA AZ ESEMÉNY ÁLTAL VÉGIGJÁRT ÖSVÉNY metaforához is közel állnak, így a végig is állhatna a ki- helyett: kijárta a gimnáziumot/az iskoláit; kifözte a lakodalmat. Ilyenek még: kiáll, kibír, kiböjtöl, kidolgoz, kiélvez, kiföz, kihallgat, kihord, kihúz, kijár, kijátszik, kikoplal, kiszolgál, kitart, kitelel, kiteleltet, kitelik, kitölt, kiül, kivár, kivív.

\subsection{A mérhetö idö: AZ IDÖ TARGY - AZ IDÖ ANYAG metaforák}

A megfoghatatlan idő valamilyen módon történő megragadása, mérése életünk meghatározó törekvése. A különféle időszámítási rendszerek, az idő mérését szolgáló eszközök erősen kultúrafüggőek, de geográfiai tényezők és gazdasági, sőt politikai szempontok is hatással vannak rájuk (Birth 1912). Időfelosztásunk, az időegységek elnevezései belesimulnak az európai keresztény időszámítás rendszerébe, csupán az egységek sorrendjében térünk el, lévén hogy a kisebbtől a nagyobb felé haladás helyett a fordított irányt alkalmazzuk: 2021. március 1 . Az egyes időegységek (perc, óra, nap stb.) meghatározása azt bizonyítja, hogy megszámolható tárgyként konceptualizáljuk öket (AZ IDŐ TÁRGY): két alma - két évszázad, két óra, két hét, két perc. Az időszakaszok körülbelüli megjelölésénél két lehetőséggel is élhetünk a magyarban: vagy a lineáris rendszerben hivatkozunk síkbeli kiterjedésére (rövid/hosszú idö), vagy AZ IDŐ 
Szili Katalin:

Az idö kifejezésének kérdéséhez a magyar nyelvben, különös tekintettel a tér és idö fogalmának összefüggésére Argumentum 17 (2021), 399-417

Debreceni Egyetemi Kiadó

DOI: $10.34103 /$ ARGUMENTUM/2021/20

ANYAG metaforára támaszkodva mennyiségi jelzőkkel illetjük: kevés, sok, temérdek csokoládé/idő stb. Hasonlóan jár el a spanyol és görög nyelv. Az oroszban (és feltehetőleg a többi szláv nyelvben is) viszont ugyancsak alkalmazhatók a kiterjedést jelölő rövid/hosszú és az anyagnevekkel használatos kifejezések: malo/mnogo vremeni-korotkoje/dlinnoje vremja.

E két metaforához természetesen különféle kifejezések, szólások, mondások is kötődnek: még egy órával megfejelte a munkaidöt; elcsípett/elvett egy fél órát az edzésböl; szakits idöt a pihenésre; Kinek bö az idö, még kifogy belöle.

\subsection{Az idő mint szociokulturális érték: $A Z$ IDÖ PÉNZ}

AZ IDŐ PÉNZ képet Lakoff és Johnson már alapírásukban meghatározzák (1980: 7-9, 161-164). Az empirikus vizsgálatok tükrében ki kell jelentenünk róla, hogy megjelenésmódja az egyes beszélőközösségek kommunikációjában erősen kultúra- és nyelvspecifikus, a pénz fogalmába tehát beépül az, hol helyezkedik el adott közösség értékrendjében a pénz, milyen az attitüdje hozzá. Azokban a kultúrákban, amelyekben az idő az értékek hierarchiájában alul helyezkedik el, kevésbé kapcsolódik össze a két fogalom, a vele szembeni magatartás semleges. A már idézett disszertációjában Sondez az arab anyagban egyáltalán nem talált nyomokat a szóban forgó kép létére (i. m. 203-204), bár megjegyzi, hogy a spend „költ” és save „megöriz, takarékoskodik" igék arab megfelelőinek létezik metaforikus használata. Az angolban ezzel szemben a két ige 21 alkalommal fordult elő metaforikus kifejezésekben korpuszában. A szóképnek a magyar nyelvben való elöfordulására rátérve, először is arra kell magyarázatot adnunk, hogy miért a tölt veszi át az angol spend „,költ” szerepét: az időm nagy részét városnézéssel töltöttem. - I spent most of my time sightseeing. Az ok, miképpen Kövecses - Benczes rámutatnak (2010: 106), az, hogy a tölt AZ IDÖ TARTÁLY metaforán alapszik, szerintem még pontosabban az előbbiekben tárgyalt, a $k i$ - igekötős igék által képviselt, AZ ESEMÉNYEK TÁRGYAK, AMIK KITÖLTIK AZ IDÖTARTÁLYT képen. Ugyancsak a szerzőpáros mutat rá az angol és magyar példák összevetésével arra, hogy a szó szerinti és elvont jelentések viszonyát tekintve legalább háromféle lehetőség merül fel a nyelvek között: 1 . azonos szó szerinti jelentés, azonos átvitt jelentés, azonos fogalmi metafora (That flat tire cost me an hour. - „A defekt egy órámba került”. 2. Eltérő szó szerinti jelentés, azonos átvitt jelentés, azonos fogalmi metafora (He is living on borrowed time „kölcsönvett időből él”- Minden nap ajándék számára; Kapott egy kis ajándékot az élettöl). Gondolatmenetük szerint a kölcsönvesz igének nincs a magyarban metaforikus jelentése, de helyettesítheti az ajándék szó, amely ugyancsak AZ IDÖ PÉNZ fogalmi metafora körébe tartozik. 3. Eltérő szó szerinti jelentés, azonos átvitt jelentés, eltérő fogalmi metafora, ezt illusztrálja a taglalt költ-tölt (Kövecses \& Benczes 2010: 121-122). A metaforát megvalósító néhány kifejezés: sok idöt vesz el, elvesztegeti/beosztja/pazarolja/rabolja az idöt, spórol az idővel. Az idő tehát általában becsülendő érték a közösségünkben (lásd nagy kincs az idő mondást), de elnyomóként, kényszerítő erőként is jelen van: nagy úr az idő; szorit a határidő.

\section{4 Összegzés}

Dolgozatomban két lépésben vizsgáltam az idő fogalmának nyelvi megjelenítését a magyar nyelvben. Első lépésben a tér, térbeli irányok kifejezésére szolgáló poliszemantikus morfológiai eszközök, esetragok, valamint névutók kapcsán kerestem a forrástartományok azon jegyeit, amelyek alapul szolgáltak a kogníció számára a tér és idő fogalmak metaforikus összekapcso- 
lására az adott funkciókban. Vizsgáltam azt is, hogy a tértől, a térbeli relációktól eredeztethető eszközök miképpen alakulnak át a lineáris időképünkben, horizontális időorientációnkban. A megfelelések elemzésével az időjelentések függetlenedésének három fokozatát tudtam elkülöníteni a ragokban, névutókban: a) a raggal álló igék lativusi vonzatából adódóan egyszerü metaforikus kiterjesztésről beszélhetünk, a két morféma teljes funkcionális elkülönülése nem történt meg, amit a közös kérdőszavaik is jeleznek; b) a rag időjelentése a térrel összefüggő jegyekből konstruálódik, de funkcionálisan független, amit kérdőszava is megerősít; c) a tér-idő megfelelés áttételes, a raghoz olyan időjelentés társul, aminek nincs térbeli megfelelője.

Második lépésben a magyar nyelvben meglévő föbb fogalmi metaforákat elemeztem, az időnek a tapasztalatainkból összeálló fő tulajdonságaira füzve fel a tárgyalásukat. Itt a további kutatásokhoz kívántam alapot nyújtani. Az azonosított metaforák többsége univerzális, a legtöbb nyelvben megvan (AZ IDŐ TÉR, AZ IDÖ MOZGÁS, AZ IDŐ TARTÁLY, AZ IDŐ FOLYÓ), ami a közös emberi tapasztalások és a hasonló kognitív feldolgozási módok bizonyítéka. Újabb adalékokkal a metaforák variációi, hangsúlyaik eltolódása szolgáltatott. Az ontológiai eredetủ térbeli irányokból - fel, le, be, ki, el - származtatható képi sémák gazdag igekötő-rendszerünknek köszönhetően igekötős igék tucatjaihoz kapcsolható metaforák létét támasztja alá: AZ IDÖ MÚLÁSA TÁVOLODÁS; AZ ESEMÉNYEK TÁRGYAK, AMELYEK MEGTÖLTIK AZ IDÖTARTÁLYT; AZ IDŐ MÚLÁSA AZ ESEMÉNY ÁLTAL VÉGIGJÁRT ÖSVÉNY. Mindkét elemzés eredményei azt igazolták, hogy időfogalmunk az univerzális tényezőkön kívül a kulturális összetevőktől függő, a nyelv meglévő eszközrendszere által is befolyásolt konceptualizációs folyamatok eredménye.

\section{Irodalom}

Ahrens, K. \& Huang, Ch. R. (2002): Time passing is motion. Language \& Linguistics 3 (3), 491-519. Retrieved from https://repository.hkbu.edu.hk/lc_ja/3.

Birth, K. (2012): Objects of Time: How things shape temporality. New York: Palgrave Macmillan.

Boroditsky, L. (2000): Metaphoric structuring: understanding time through spatial metaphors. Cognition 43, 1-22. https://doi.org/10.1016/S0010-0277(99)00073-6

Boroditsky, L. (2001): Does language shape thought? Mandarin and English speakers' conceptions of time. Cognitive Psychology 43, 1-22. https://doi.org/10.1006/cogp.2001.0748

Caballero, R. \& Ibarretxe-Antuñano, I. (2014): Ways of perceiving, moving, and thinking: Revindicating culture in conceptual metaphor research. Journal of Cognitive Semiotics Vol. V., 1-2, 268-290.

Clark, H. H. (1973): Space, time, semantics, and the Child. In: Moore, T. E. (ed.): Cognitive development and the acquisition of language. New York: Academic Press, 27-63. https://doi.org/10.1016/B978-0-12-505850-6.50008-6

Evans, V. (2003): The structure of time: Language, meaning, and temporal cognition. Amsterdam: John Benjamins.

ÉrtSz. (1960): A magyar nyelv értelmező szótára. Budapest: Akadémiai Kiadó.

Fauconnier, G. \& Turner, M. (2008): Rethinking metaphor. In: Gibbs, R. (ed.): The Cambridge Handbook of Metaphor and Thought. Cambridge: Cambridge University Press, 53-66. https://doi.org/10.1017/CBO9780511816802.005 
Freeman, M. H. (2004). Crossing the Boundaries of Time: Merleau-Ponty's Phenomenology and Cognitive Linguistic Theories. Linguagem, Cultura e Cognição: Estudos de Linguística Cognitiva Vol. 2, 643-655.

Gentner, D. M. I. \& Boroditsky, L. (2002): As time goes by: Evidence for two systems in processing space. Space metaphors. Languge and Cognitive Processes 17 (5), 537-565. https://doi.org/10.1080/01690960143000317

Haspelmath, M. (1997): From space to time: Temporal adverbials in the world's languages. München, Newcastle: Lincom Europa.

Heine, B., Claudi, U. \& Hünnemeyer, F. (1991): Grammaticalization: A Conceptual Framework. Chicago: University of Chicago Press.

Kövecses, Z. (2005a): A metafora. Gyakorlati bevezetés a kognitív metaforaelméletbe. Budapest: Typotex.

Kövecses, Z. (2005b): Metaphor in culture: Universality and variation. Cambridge, New York: Cambridge University Press. https://doi.org/10.1017/CBO9780511614408

Kövecses, Z. (2006): Language, Mind and Culture: a Practical Introduction. New York: Oxford University Press.

Kövecses, Z. \& Benczes, R. (2010): Kognitív nyelvészet. Budapest: Akadémiai Kiadó.

Lakoff, G. (1993): The contemporary theory of metaphor. In: Ortony, A. (ed.): Metaphor and Thought. Second Edition, Cambridge: Cambridge University Press. https://doi.org/10.1017/CBO9781139173865.013

Lakoff, G. (1994): What is a conceptual system? In: Willis, F. O. \& Palermo, D. S. (eds.): The nature and ontogenesis of meaning. Hillsdale, N. J.: Laurence Erlbaum, 41-90.

Lakoff, G. \& Johnson, M. (1980): Metaphors we live by. Chicago: University of Chicago.

Lakoff, G. \& Johnson, M. (1999): Philosophy in the Flesh. New York: Basic Books.

Lakoff, G. \& Turner, M. (1989): More Than Cool Reason: A Filed Guide to Poetic Metaphor. Chicago: The University of Chicago Press. https://doi.org/10.7208/chicago/9780226470986.001.0001

Merleau-Ponty, M. (1962): Phenomenology of perception. London: Routledge \& Kegan Paul.

Moore, K. E. (2006): Space-to-time mappings and temporal concepts. Cognitive Linguistics 17, 199-244. https://doi.org/10.1515/COG.2006.005

Moore, K. E. (2014): Spatial Language of Time. Metaphor, metonymy, and frames of reference. Amsterdam: John Benjamins. https://doi.org/10.1075/hcp.42

Rácz, E. (1968): Az időhatározó. In: Rácz E. (szerk.): A mai magyar nyelv. Budapest: Tankönyvkiadó, 299-302.

Radden, G. (2006): Where time meets space. In: Benczes, R. \& Csábi, Sz. (eds.): The Metaphors of Sixty: Papers presented on the occasion of the 60th birthday of Zoltan Kövecses. Budapest: Eötvös Loránd University.

Radden, G. (2011): Spatial time in the West and the East. In: Brdar, M., Omazic, M., Pavicic Takac, V., Gradecak-Erdeljic, T. \& Buljan, G. (eds.): Space and Time in Language. Frankfurt: Peter Lang, 1-40.

Sinha, C. \& Bernárdez, E. (2015): Space, time and space-time: Metaphors, maps and fusions. In: Sharifian, F. (ed.): The Routledge Handbook of Language and Culture. New York: Routledge, 309-324.

Smart, J. J. C. (1949): The river of time. Mind. Vol. 58, 483-494. https://doi.org/10.1093/mind/LVIII.232.483 
Szili Katalin:

Az idö kifejezésének kérdéséhez a magyar nyelvben, különös tekintettel a tér és idö fogalmának összefüggésére Argumentum 17 (2021), 399-417

Debreceni Egyetemi Kiadó

DOI: $10.34103 / A R G U M E N T U M / 2021 / 20$

Sondes, H. (2008): Conceptual metaphors of time in English and in Arabic: a comparative cognitive study. Québec: Departement de langues, linguistique et traduction, Faculté des Lettres, Université Laval.

Stocker, K. (2014): The Theory of Cognitive Spacetime. Metaphor and Symbol 29 (2), 71-93. https://doi.org/10.1080/10926488.2014.889991

Szabó, R. (2015): Metaforák és szimbólumok.C. G. Jung szimbólumértelmezésének és a fogalmi metaforák elméletének összevetése. Budapest: Oriold és Társai.

Szamarasz, V. Z. (2006): Az idő téri metaforái: a metaforák szerepe a feldolgozásban. Világosság 8-9-10, 99-109.

Szili, K. (2003): A ki igekötő jelentésváltozásai. Magyar Nyelv 102 (2), 163-188.

Szili, K. (2006): Az ellentétes jelentésü igekötők formai és szemantikai kapcsolatának kérdéséhez a be és ki igekötők kapcsán. In: Mártonfi, A., Papp, K. \& Slíz, M. (szerk.): 101 írás Pusztai Ferenc tiszteletére. Debrecen: Argumentum Kiadó, 411-416.

$\mathrm{Yu}, \mathrm{N}$. (2012): The metaphorical orientation of time in Chinese. Journal of Pragmatics 44, 1335-1354. https://doi.org/10.1016/j.pragma.2012.06.002

Waliński, J. T. (2014): Complementaritiy of space and time in distance representation. Łódź: Uniwersytet Łódź. https://doi.org/10.18778/7969-441-9

Zaicz, G. (föszerk.) (2006): Etimológiai szótár. Budapest: Tinta Könyvkiadó.

Szili Katalin

Magyar Nyelv és Kultúra Intézete

Prešovska univerzita v Prešove

17. novembra, 15. 08001 Prešov

katalin.szili@unipo.sk

szilikatalin5@gmail.com 